\title{
Gastric proliferative lesions induced by duodenogastric reflux in rats ${ }^{1}$
}

\author{
Lesões proliferativas gástricas induzidas pelo refluxo duodenogástrico em ratos
}

\author{
Rosângela Lucinda Rocha Monteiro², Nelson Adami Andreollo ${ }^{3}$, Maria Aparecida Marchesan Rodrigues ${ }^{4}$, \\ Marina Raquel Araujo ${ }^{5}$
}

1. Master's Thesis presented at the Post Graduation Program in Surgery of the School of Medical Science (FCM) of the State University of Campinas (UNICAMP). São Paulo, Brazil.

2. Assistant Professor at the School of Medicine of Pouso Alegre, University of Vale do Sapucaí (UNIVAS). Brazil.

3. Associate Professor of the Department of Surgery, UNICAMP. Brazil.

4. Faculty Member of the Department of Pathologic Anatomy at the School of Medicine of Botucatu (UNESP). Brazil.

5. Biologist of the Laboratory of Enzymology and Experimental Carcinogenesis (UNICAMP). Brazil.

\begin{abstract}
Purpose: To analyze mucosal proliferation and its characteristics, through specific models of duodenogastric reflux, in the stomach of Wistar rats. Methods: Seventy-five healthy and adult male rats were divided into three groups: group I control ( $n=25$ animals), submitted to gastrotomy of the posterior wall of the glandular stomach; group II - DGR ( $n=25$ animals), submitted to duodenogastric reflux through latero-lateral gastrojejunal anastomosis in the posterior wall of the glandular stomach and group III - DGR-P (n = 25 animals), submitted to duodenogastric reflux through the pylorus following the same procedure of group II, sectioning and closing the afferent loop. The animals were observed during 36 weeks and subsequently the mucosal lesions were analyzed, with macroscopic and microscopic examination of the prepyloric, the gastrojejunostomy and the squamous area of the stomach. Results: Group I did not present any kind of lesion. Macroscopic lesions of the prepyloric area in groups II and III were $0 \%$ and $20 \%$, respectively. Macroscopic lesions of the gastrojejunal stoma in groups II and III were $36 \%$ and $88 \%$, respectively, and $12 \%$ and $28 \%$, respectively, in the squamous area. Microscopically, adenomatous hyperplasia (AH), squamous hyperplasia ( $\mathrm{SH}$ ) and adenocarcinoma (AC) were diagnosed. The occurrence of $\mathrm{AH}$ at the prepyloric area in groups II and III was $0 \%$ and $40 \%$, respectively, and in the gastrojejunal stoma, $40 \%$ and $72 \%$, respectively. The occurrence of $\mathrm{SH}$ in the squamous area in groups II and III was $12 \%$ and $20 \%$, respectively, without statistical differences between the groups. AC was found only in three animals of groups III (12\%). Conclusions: The duodenogastric reflux in this experimental model caused high frequency of proliferative lesions of the gastrojejunal stoma and in the prepyloric area, while adenocarcinoma was a rare occurrence.
\end{abstract}

Key words: Duodenogastric Reflux. Hyperplasia. Adenocarcinoma. Rats.

\section{RESUMO}

Objetivo: Avaliar as lesões proliferativas que se desenvolvem na mucosa gástrica de ratos Wistar após modelo específico de refluxo duodeno-gástrico. Métodos: Foram utilizados 75 ratos adultos machos divididos em três grupos experimentais: o grupo I (controle) submetido a gastrotomia na parede posterior do estômago glandular (25 animais); o grupo II (RDG), foi submetido a gastrojejunoanastomose látero-lateral na parede posterior do estômago glandular (25 animais) e o grupo III (RDG-P) submetido a gastrojejunoanastomose látero-lateral na parede posterior do estômago glandular, com secção e fechamento da alça (25 animais). Os animais foram observados durante 36 semanas, após o que foram realizados estudos macroscópicos e microscópicos da anastomose gastrojejunal, da região pré-pilórica e região escamosa do estômago. Resultados: Os animais do Grupo I não apresentaram nenhum tipo de lesão. No grupo II observou-se $40 \%$ de lesões do tipo hiperplasia adenomatosa na anastomose e $12 \%$ de hiperplasia escamosa. No grupo III obteve-se $40 \%$ de hiperplasia adenomatosa na mucosa pré-pilórica, 72 \% de hiperplasia adenomatosa na mucosa da anastomose, 20\% de hiperplasia escamosa e 12 \% de adenocarcinoma. Conclusões: O refluxo duodeno-gástrico induz a alta freqüência de lesões proliferativas na mucosa adjacente à anastomose gastrojejunal ou na mucosa pré-pilórica e o adenocarcinoma é um evento raro neste modelo experimental.

Descritores: Refluxo Duodenogástrico. Hiperplasia. Adenocarcinoma. Ratos.

\section{Introduction}

The gastric mucosa is particularly susceptible to the onset of proliferative lesions when submitted to reflux of the duodenal content ${ }^{1,2}$. Several investigations were carried out to clarify whether patients undergoing surgery with techniques that promote duodenogastric reflux, such as partial gastrectomies in case of benign disorders, would be 
at higher risk than the non-gastrectomized population for development of cancer of the remaining gastric stump $p^{3,4,5}$. Since the start of the 80 s decade, by means of wellconducted research, it has been definitively established that patients submitted to techniques that promote duodenogastric reflux, such as Billroth II reconstruction, are more susceptible to neoplasia after a postoperative period longer than 20 years s,7,8,9 $^{6}$

At present, authors endeavor to better evaluate the potential relationship between the primary duodenogastric reflux that takes place through the pylorus in fasting and postprandial conditions, in non-operated stomachs, and neoplastic development ${ }^{10,11,12,13}$. Most of stomach neoplasias appear in an environment of chronic atrophic gastritis with intestinal metaplasia ${ }^{11}$. The intensity of glandular atrophy and intestinal metaplasia is directly related to the reflux of duodenal secretions in the gastric mucosa ${ }^{14}$.

Considering the divergent results in the literature regarding the frequency of gastric adenocarcinoma in experimental models that produce duodenogastric reflux, we proposed to carry out an experimental study with the objective of diagnosing the nature of these proliferative lesions. Our model investigates one of the variations, since the gastrojejunal anastomosis is situated in the posterior wall of the glandular stomach.

\section{Methods}

Seventy-five male Wistar rats, approximately three months old and weighing between 180 and 280 g were divided into three experimental groups. The number of participating animals was calculated based on proportional sample size (descriptive study - qualitative variable). The groups were organized as follows:

Group I (control) - 25 animals submitted to median laparotomy, followed by gastrotomy of the posterior wall of the glandular stomach with manipulation of intestinal loops, closure of the stomach by means of continuous polypropylene suture and India ink markings for posterior identification (Figure 1).

Group II (DGR) - 25 animals submitted to median laparotomy with identification of the duodenum, at a $4 \mathrm{~cm}$ distance from the pylorus, with opening of the intestinal loop and gastric mucosa, with gastrojejunal anastomosis in the isoperistaltic direction of the loop and the posterior wall of the glandular stomach (Figure 2).

Group III (DGR-P) - 25 animals submitted to gastrojejunal anastomosis similar to group II, but with section and ligature of the afferent loop, inducing duodenogastric reflux through the pylorus (Figure 3).

All of the animals were observed and sacrificed after 36 weeks. The surgical pieces were removed under ether anesthesia and median laparotomy, following exploration of the peritoneal cavity. The stomach was opened at its greater curvature, and the duodenum and the jejunum segment at the mesenteric border. The pieces were then washed in saline, identified and photographed. The pieces were extended on polystyrene plaques with the serous surface down, secured with pins, fixed in $10 \%$ formaldehyde solution and plugged with a tampon for 24 hours and then in $70 \%$ alcohol.The squamous mucosa and the gastric mucosa were then transversally cut at the anastomosis and pylorus level, obtaining 2 fragments of about $2 \mathrm{~mm}$ from each segment. The fragments were identified, placed in vessels with $10 \%$ formaldehyde solution and processed by the usual methods to obtain histological cuts, which were stained by hematoxylin and eosin.

The protocol for the histological analysis was prepared, including the following criteria:

Squamous Hyperplasia - diagnosed when the stratified squamous epithelium is two or more times thicker than normal, with hyperkeratosis.

Adenomatous Hyperplasia - characterized by proliferation of glandular structures, with endophytic or exophytic growth regarding the submucosa and absence of cellular atypia.

Adenocarcinoma - differentiated from the previously described lesion by the mandatory presence of severe cellular and structural atypias, as well as by invasive growth.

The statistical analysis employed the Chi-square test and Fischer's exact tests, with a $5 \%$ level of significance ${ }^{15}$.

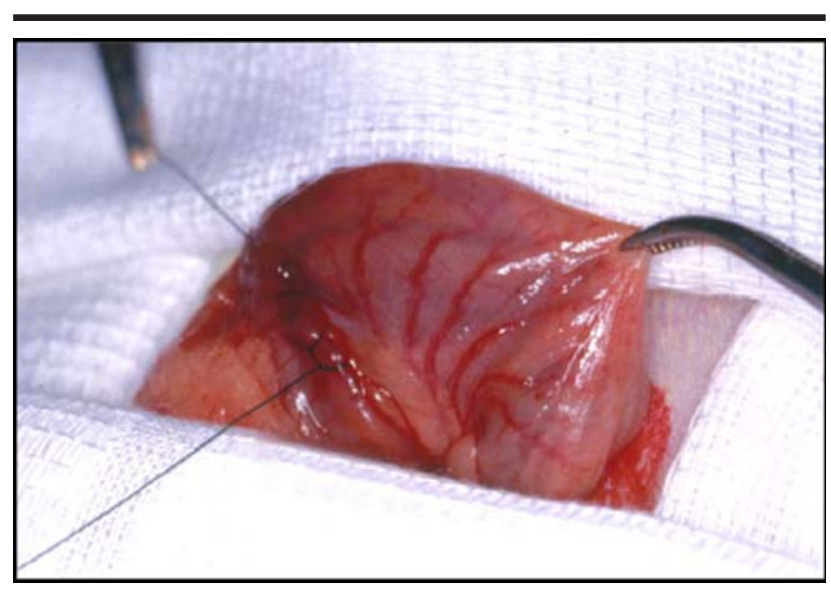

FIGURE 1 - Group I. Gastrotomy of the posterior wall of the glandular stomach

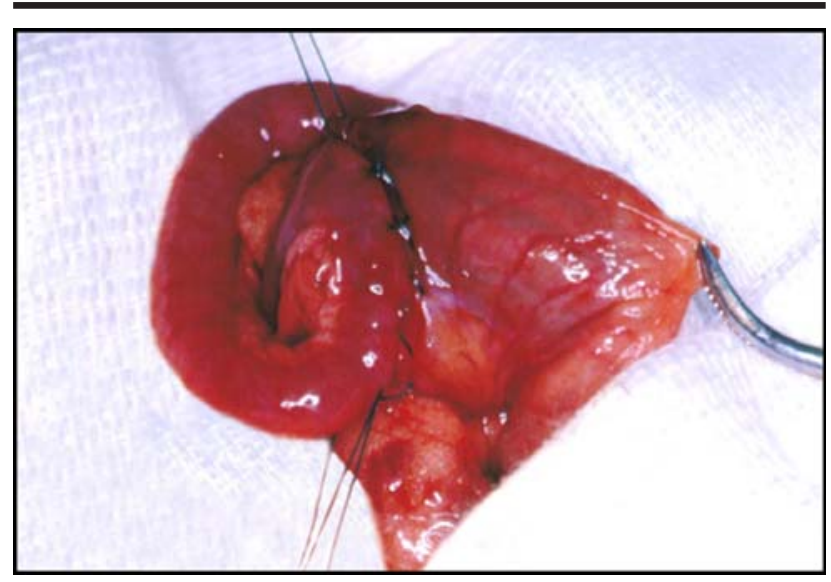

FIGURE 2 - Group II. DGR - Gastrojejunal anastomosis of the posterior wall of the glandular stomach at a $4 \mathrm{~cm}$ distance from the pylorus 


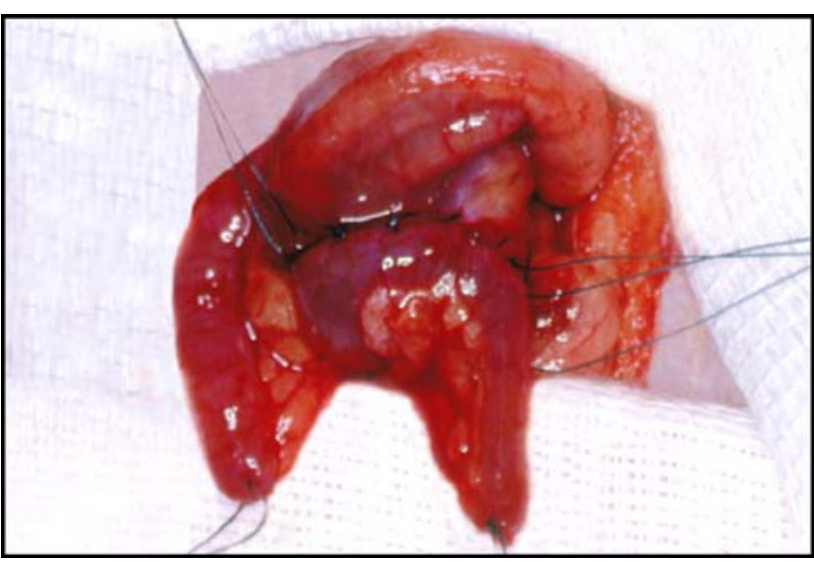

FIGURE 3 - Group III. DGR-P- Gastrojejunal anastomosis with section and ligadure of the afferent loop, induncing duodenogastric reflux through the pylorus

\section{Results}

The macroscopic alterations found were identified as polypoid vegetative lesions or sessile, of varied sizes, at the gastrojejunal anastomosis level and some in the prepyloric mucosa in group III. In group I, no macroscopic lesions were identified except for discrete prominence of the mucosa at the gastrotomy location.

Table 1 demonstrates the percentages of macroscopic lesions found in the studied groups:

TABLE 1 - Percentages of macroscopic lesions (\%) and respectives location in surgical pieces in the groups I (control), II (DGR) and III (DGR-P), n= actual number of animals

\begin{tabular}{ccccc}
\hline Groups & $\mathrm{n}$ & $\begin{array}{c}\text { Squamous Stomach } \\
(\%)\end{array}$ & $\begin{array}{c}\text { Anastomosis } \\
(\%)\end{array}$ & $\begin{array}{c}\text { Prepyloric } \\
(\%)\end{array}$ \\
\hline I & 25 & 0 & 0 & 0 \\
II & 25 & $3(12 \%)$ & $9(36 \%)$ & 0 \\
III & 25 & $7(28 \%)$ & $22(88 \%)$ & $5(20 \%)$ \\
\hline
\end{tabular}

Figures 4, 5 and 6 below show the stomachs of opened animals and the aspect of the macroscopic lesions found:

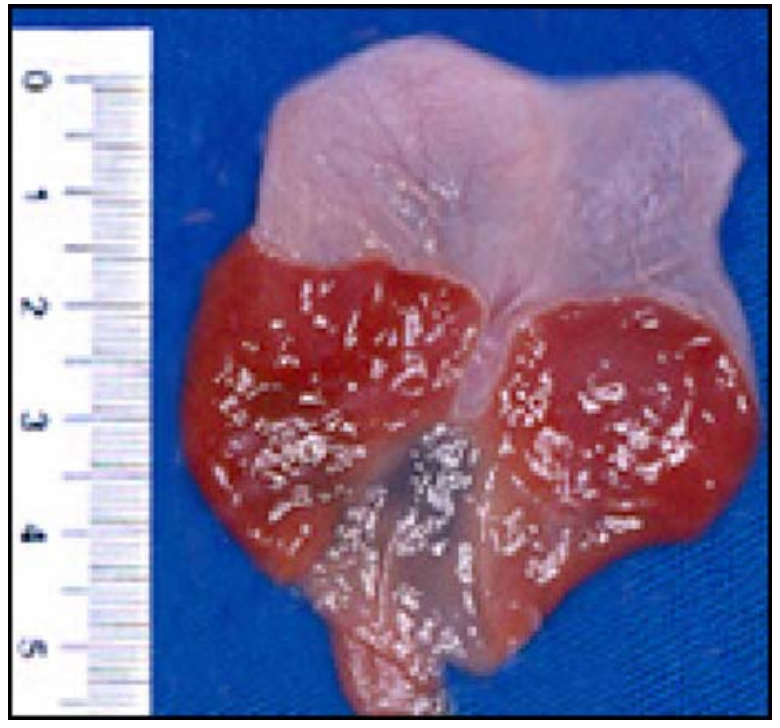

FIGURE 4 - Group I. Normal mucosa of squamous region and glandular stomach

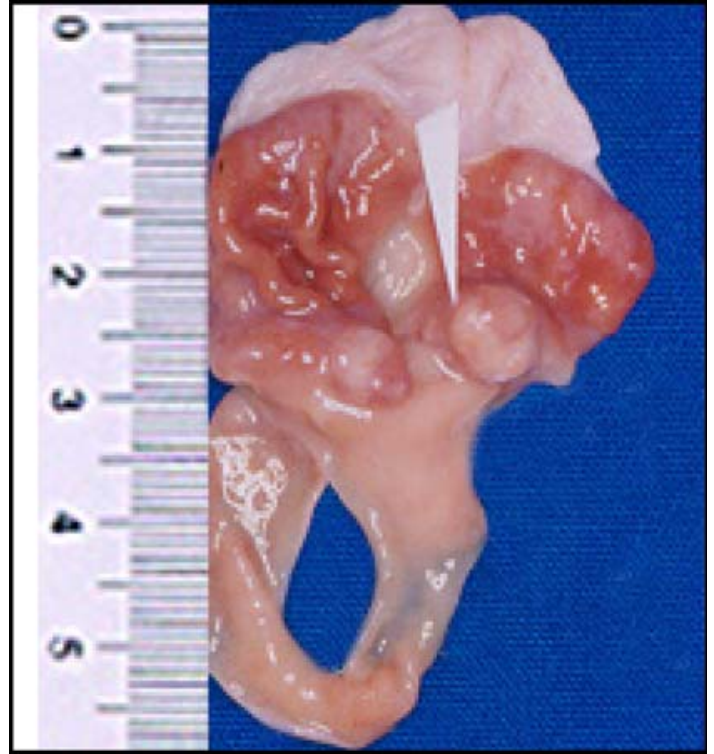

FIGURE 5 - Group II. DGR - Adenomatous Hyperplasia at the gastrojejunal anastomosis 


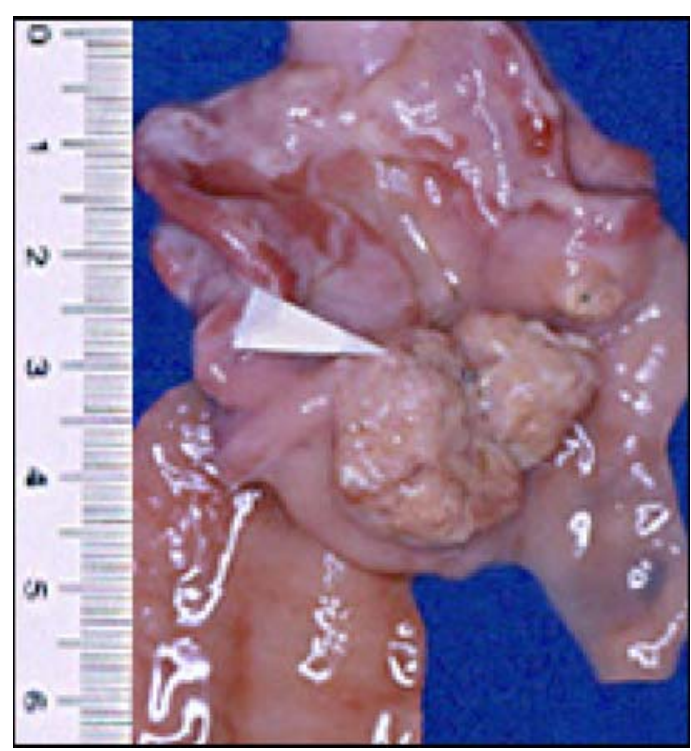

FIGURE 6 - Group III. DGR-P-Adenocarcinoma at the gastrojejunal anastomosis

It should be noted that the macroscopic lesions were more numerous both in the squamous stomach, in the anastomosis and in the prepyloric region of Group III (DGRP), with statistical difference when compared to Group II (DGR) $(\mathrm{p}<0.05)$.

The histopathological analysis was quite detailed and the analyzed gastric regions were:

- Mucosa at the anastomosis level (glandular stomach);

- Mucosa at the level of the squamous region;

- Prepyloric mucosa

The proliferative lesions found and analyzed were adenomatous hyperplasia, squamous hyperplasia and adenocarcinoma, as can be seen in Figures 7, 8 and 9 below:

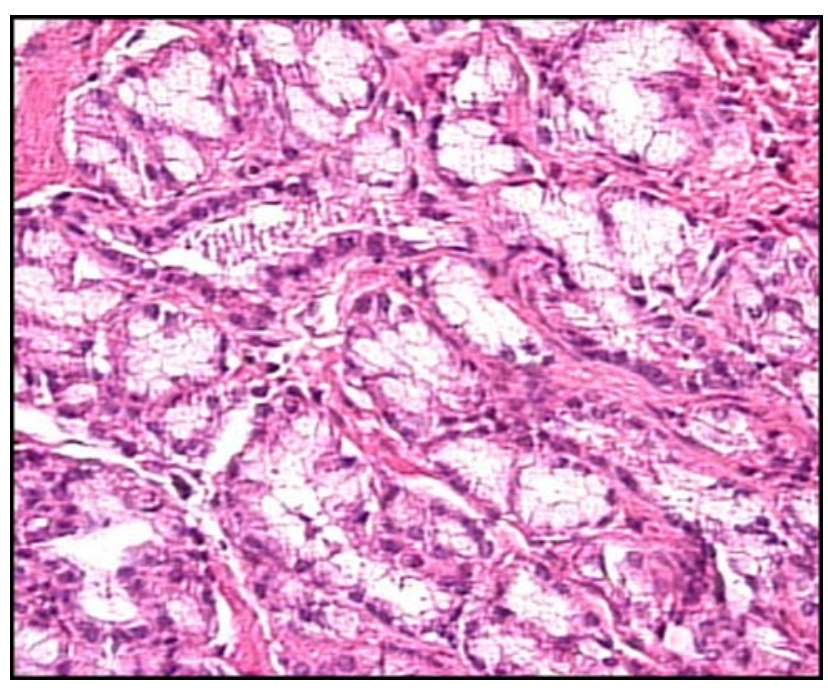

FIGURE 7 - Adenomatous Hyperplasia (200x). Gastrojejunal anastomosis in Group II (Control)

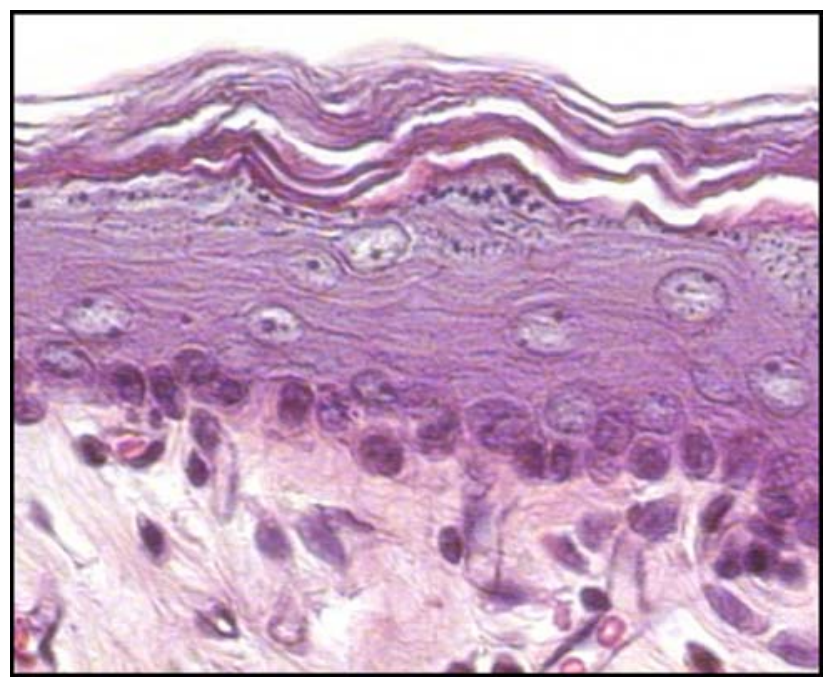

FIGURE 8 - Squamous Hyperplasia (200x). Squamous epithelium in Group III (DGR)

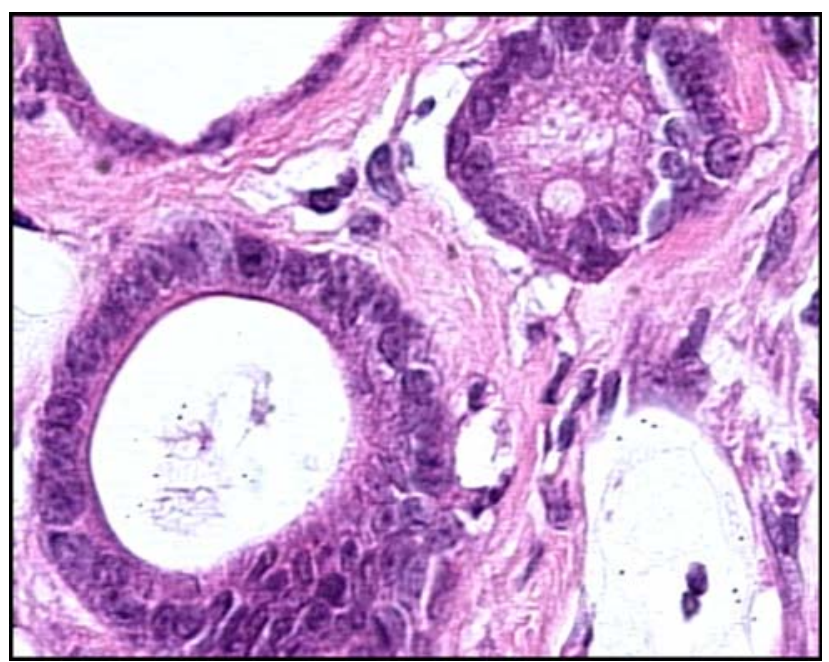

FIGURE 9 - Adenocarcinoma (200x). Gastrojejunal anastomosis in Group III (DGR-P)

Table 2 demonstrates the percentages of histological lesions (\%) in the prepyloric mucosa and in anastomosis in the studied groups.

It should be noted that in group III (DGR-P), adenomatous hyperplasia was more frequent when compared with group II (DGR), both in the prepyloric region and at the anastomosis site, with a significant statistical difference $(\mathrm{p}<0.05)$.

Table 3 below shows the percentages of squamous hyperplasia found in the studied groups.

The percentages of squamous hyperplasia did not differ between groups GII (DGR) and GIII (DGR-P) ( $p>0.05)$.

Three lesions of the mucous adenocarcinoma type were diagnosed at the gastrojejunal anastomosis site in group III, during the histological examination. These lesions are characterized by atypical columnar cells disposed in small 
blocks or strings, amid abundant stroma composed of mucous lakes. Table 4 demonstrates the percentage of mucous adenocarcinoma found in the gastrojejunal anastomosis mucosa.

It may be observed that adenocarcinoma occurred only in the gastrojejunal anastomosis mucosa of group III (DGRP) with duodenogastric reflux through the pylorus.

TABLE 2 - Percentages of histological lesions (\%) in the prepyloric mucosa and in anastomosis in the groups GI (control), GII (DGR) and GIII (DGR-P) $\mathrm{n}=$ actual number of animals: $\mathrm{AH}=$ Adenomatous Hyperplasia AC= Adenocarcinoma

\begin{tabular}{lcccccc}
\hline Groups & $n$ & \multicolumn{2}{c}{$\begin{array}{c}\text { Prepyloric } \\
(\%)\end{array}$} & & \multicolumn{2}{c}{$\begin{array}{c}\text { Anastomosis } \\
(\%)\end{array}$} \\
\cline { 3 - 4 } \cline { 6 - 7 } & & AH & AC & & AH & AC \\
\hline I & 25 & 0 & 0 & & 0 & 0 \\
II & 25 & 0 & 0 & & $10(40 \%)$ & 0 \\
III & 25 & $10(40 \%)$ & 0 & & $18(72 \%)$ & $3(12 \%)$ \\
\hline
\end{tabular}

TABLE 3 - Percentages of squamous hyperplasia (\%) in the groups I (Control), GII (DGR) and GIII (DGR-P) $\mathrm{n}=$ actual number of animals.

\begin{tabular}{llc}
\hline Groups & n & Squamous Hyperplasia \\
\hline Control & 25 & 0 \\
DGR & 25 & $3(12 \%)$ \\
DGR-P & 25 & $5(20 \%)$ \\
\hline
\end{tabular}

TABLE 4 - Percentage of mucous adenocarcinoma (\%) in gastrojejunal anastomosis mucosa $\mathrm{n}=$ actual number of animals

\begin{tabular}{llc}
\hline Groups & n & Adenocarcinoma \\
\hline I & 25 & 0 \\
II & 25 & 0 \\
III & 25 & $3(12 \%)$ \\
\hline
\end{tabular}

\section{Discussion}

A review of the experimental research literature on the induction of duodenogastric reflux shows great divergence in relation to the results, probably due to the diversity of surgical techniques used, which alter the degree of reflux, as well as the histopathological criteria adopted.

The spontaneous neoplastic development rarely occurs in the glandular stomach of Wistar rats. Most of the experimental studies employ $\mathrm{N}$-nitrous compounds or nitrosamines to induce stomach carcinomas in experimental animals and the rat offers the most facilities for research, both of proliferative lesions and carcinogenesis ${ }^{4,16}$.

The duodenogastric reflux may be obtained through gastric resection or not. Gastric resection models simulate the existing techniques in surgical clinic (Billroth I or II), accompanied or not by truncal vagotomy ${ }^{3,4,17,18}$.

In 1991, Kobayasi et al. ${ }^{19}$ investigated the influence of the duodenogastric reflux in four groups of Wistar rats subjected to Billroth II gastrectomy, Billroth II gastrectomy with conversion to Roux-en-Y at 24 weeks, Billroth II gastrectomy with conversion to Roux-en-Y at 36 weeks and basic gastrectomy with Roux-en-Y reconstruction. In that study, the selected histological criteria were identical to those of the present investigation, considering the degree of cellular atypias for diagnosis of adenocarcinoma and the benign lesions classified as squamous hyperplasia or adenomatous hyperplasia. The authors have concluded, through histochemical examination, that the benign proliferative lesions presented the phenotype of gastric cells and the malignant lesions presented the phenotype of small intestine cells. They also concluded that the benign proliferative lesions do not progress to adenocarcinoma and that their incidence decreases if the duodenogastric reflux is interrupted with the conversion to Roux-en-Y.

The possible mechanisms through which the duodenogastric reflux would cause stomach cancer are controversial. One of them would be the proliferation of bacteria in the lumen of the organ, which would lead to an increase in nitrate-reducing bacteria and induce $\mathrm{N}$-nitrous compound formation. The action of billiary acids and lysolecithin in the duodenal juice could also destroy the lipoprotein membrane that protects the mucosa ${ }^{1,16}$.

In 2002, Rodrigues et al. ${ }^{20}$ investigated the effect of duodenal secretion reflux in groups of Wistar rats, with 3 experimental groups: G1 (control), G2 (submitted to gastrojejunal anastomosis and 2 weeks later to ligature of the afferent loop, deviating secretions through the pylorus) and G3 (gastrojejunal anastomosis; after the $36^{\text {th }}$ week, alimentary transit was reestablished by latero-lateral anastomosis between the afferent and efferent loops. After a period of 54 weeks, the author concluded that the reflux through the pylorus favored the development of predominantly benign proliferative lesions in the gastric mucosa. The interruption of reflux caused an inhibiting effect on the growth of these lesions, confirming the benign histological characteristic of these lesions. The neoplastic development was rare in this experimental model.

Recent publications emphasized the mutagenic potential of duodenogastric reflux, both for the gastric and for the esophageal mucosa, associating it even to the occurrence of Barrett's esophagus and adenocarcinoma that appears on this epithelium ${ }^{2,5,13}$. Ovrebo et al. ${ }^{21}$ studied the histological alterations in the gastric mucosa of rats 24, 36 and 52 weeks after gastrojejunal anastomosis, concluding that the ulcers and carcinomas appear more frequently in the body than in the antrum, with ulcers preceding the onset of carcinomas

In this research, the anastomosis was located in the posterior wall of the glandular stomach and its purpose was to compare with data in the literature whether the anastomosis location would influence the incidence of proliferative lesions in the gastric mucosa. Adenomatous hyperplasia was diagnosed predominantly at the gastrojejunal anastomosis level, presenting benign 
characteristics and in compliance with data in the literature. It was much more frequent in group III, in which the animals had the duodenum closed, so that the duodenal content had to pass through the stomach. Its benign characteristics suggest that if the animal were operated again $\mathrm{AH}$ might regress, as previously demonstrated by other authors ${ }^{19,20}$. In the squamous epithelium that lines the proximal third of the stomach the presence of squamous hyperplasia was found, with a frequency that did not significantly differ between the animals in groups II and III. These results differ from those obtained by Miwa et al. ${ }^{11}$ that reported development of squamous cell carcinoma in a model of induction of duodenogastric reflux similar to the present study, although the follow-up period was 50 weeks and the anastomosis was located close to the greater curvature of the squamous stomach.

The adenocarcinoma diagnosed was of the mucous type and was found in $12 \%$ of the animals in group III at the gastrojejunal anastomosis level. These results were similar to those found by the authors that used the same technique for induction of duodenogastric reflux ${ }^{18,19,22}$. Detailed studies by Rodrigues et al. ${ }^{23}$ conclude that the adenocarcinoma induced by duodenogastric reflux is morphologically and histologically different from that occurring in the stomachs of animals following the use of nitrosamines.

In other experimental models employing Billroth II gastrectomies the incidence is high, while practically nonexistent in Roux-en-Y reconstructions, demonstrating that the determining factor is the duodenogastric reflux. The time of exposure to reflux is also a determining factor for the onset of such lesions, as found by Liu et al. ${ }^{24}$ in their 2003 study, who did not diagnose adenocarcinomas after a 3-week follow-up.

The results of this research show that the duodenogastric reflux induced high frequency of proliferative lesions with benign histopathological characteristics in the mucosa adjacent to the gastrojejunal anastomosis or the prepyloric mucosa, and that carcinomas are rare in this experimental model.

The research in the area of experimental gastric carcinogenesis has been achieving significant advancement with the aid of molecular biology, opening new perspectives to future studies and contributing for the elucidation of the complex neoplastic transformation process.

\section{Conclusions}

The duodenogastric reflux after gastrojejunal anastomosis in the posterior wall of the stomach of Wistar rats induces a high frequency of proliferative lesions in the mucosa adjacent to the anastomosis or in the prepyloric mucosa. The histopathological characteristics of these lesions are benign and the occurrence of carcinomas not frequent in this experimental model.

\section{References}

1. Miwa K, Hasegawa H, Fugimura T, Matsumoto H, Mitaya R, Kosaka T, Miyasaki I, Hattori T. Duodenal reflux trought the pylorus induces gastric adenocarcinoma in the rat. Carcinogenesis. 1992;13: 2313-6.

2. Mukaisho K, Miwa K, Kumagai H, Bamba M, Sugihara $\mathrm{H}$, Hattori T. Gastric carcinogenesis by duodenal reflux through gut regenerative cell lineage. Dig Dis Sci. 2003;48(11):2153-8.

3. Houghton PWJ, Mortensen NJM, Williamson RCN. Effect of duodenogastric reflux on gastric mucosal proliferation after gastric surgery. Br J Surg. 1987;74:288-91.

4. Andreollo NA, Brandalise NA, Lopes LR, Leonardi LS, Alcantara F. Are the nitrites and nitrates responsible for the carcinoma in the operated stomach ? Acta Cir Bras. 1995;10(3):103-6.

5. Theisen J, Peters JH, Fein M, Hughes M, Hagen JA, Demeester SR, Demeester TR, Laird PW. The mutagenic potential of duodenoesophageal reflux. Ann Surg. 2005;241(1):63-8.

6. Cayagill CPJ, Hill MJ, Hall CN, Kirkhan JS, Northfield, TC. Mortality from gastric cancer following gastric surgery for peptic ulcer. Lancet. 1986;1:929-31.

7. Lundegardh G, Adami HD, Helmick C, Zack M, Meirik O. Stomach cancer after partial gastrectomy for benign ulcer disease. N Engl J Med. 1988;319:195-200.

8. Tersmette KWF, Stijnen TH, Hoedemaecker J, Vanderbroucke JP, Tytgat GN. Mortality caused by stomach cancer after remote partial gastrectomy for benign conditions: 40 years of follow-up of an Amsterdam cohort of 2633 postgastrectomy patients. Gut. 1988;29:1588-9.

9. Toftgaard C. Gastric cancer after peptic ulcer surgery: a historic prospective cohort investigation. Ann Surg. 1989;210:159-64.

10. Attwood SEA, Smyrk TC, De Meester TR, Mirvish SS, Stein HJ, Hinder RA. Duodenoesophageal reflux and development of esophageal adenocarcinoma in rats. Surgery. 1992;111:503-10

11. Miwa K, Hasegawa M, Takano Y, Matsumoto H, Sahara H, Yagi M, Miyasaki I, Hattori T. Induction of oesophageal and forestomach carcinomas in rats by reflux of duodenal contents. Br J Cancer. 1994;70:185-9.

12. Miwa K, Hattori T, Miyasaki I. Duodenogastric reflux and foregut carcinogenesis. Cancer. 1995;75:1426-32.

13. Koek GH, Vos R, Sifrim D, Cuomo R, Janssens J, Tack J. Mechanisms underlying duodeno-gastric reflux in man. Neurogastroenterol Motil. 2005;17(2):191-9.

14. Sobala GM, O’Connor HJ, Dewar EP, King RFG, Axon ATR, Dixon NF. Bile reflux and intestinal metaplasia in gastric mucosa. J Clin Pathol. 1993;46:235-40.

15. Fonseca JL, Martins GA. Curso de estatística. 5ed. São Paulo: Editora Atlas; 1994.

16. Mirvish S S. The etiology of gastric cancer: intragastric 
nitrosamine and other theories. J Natl Cancer Inst. 1983;71:629-47.

17. Langhans P, Heger RA, Stegemann B. The cancer risk in the stomach subjected to nonresecting procedures. Scand J Gastroenterol. 1984;92,138-41.

18. Saad LHC. Lesões da mucosa do coto gástrico após reconstrução a Billroth II e em Y de Roux, em ratos [Dissertação - Mestrado]. Botucatu: Faculdade de Medicina, Universidade Estadual Paulista "Júlio de Mesquita Filho”; 1993.

19. Kobayasi S, Tatematsu M, Ogawa K, Camargo JLV, Rodrigues MAM, Ito N. Reversibility of adenomatous hyperplasia in the gastric stump after diversion of the bile reflux in rats. Carcinogenesis. 1991;12:1437-43.

20. Rodrigues PA, Naresse LE, Leite CVS, Rodrigues MAM, Kobayasi S. O refluxo duodeno-gástrico (RDG), através do piloro, induz lesões proliferativas gástricas em ratos ? Acta Cir Bras. 2002;17(3):160-7.

21. Ovrebo KK, Aase S, Grong K, Viste A, Svanes K, Sorbye
H. Ulceration as a possible link between duodenogastric reflux and neoplasms in the stomach of rats. J Surg Res. 2002;107(2):167-78.

22. Rodrigues PA. Prevenção das lesões proliferativas da mucosa do coto gástrico de ratos gastrectomizados à Billroth II, através de derivação em Y de ROUX com ou sem vagotomia [Dissertação - Mestrado]. Botucatu: Faculdade de Medicina, Universidade Estadual Paulista "Júlio de Mesquita Filho"; 1995.

23. Rodrigues MA, Kobayasi S, Naresse LE, de Souza Leite CV, Nakanishi H, Imai T, Tatematsu M. Biological differences between reflux stimulated proliferative stomal lesions and N-methyl-N'-nitro-N-nitrosoguanidine induced carcinomas in Wistar rats. Cancer Lett. 1999;145(1-2):85-91.

24. Liu JX, Liu XG, Dai Y, Tang XY, Li J, Wang HH. An experimental on gastric mucosal damage induced by duodenogastric reflux in rats. Zhonghua Nei Ke Za Zhi. 2003;42(12):837-9.

\section{Correspondência:}

Rosângela Rocha Monteiro

Rua Amadeu Bertolacini, 20

37.564-000 Borda da Mata - MG Brazil

mrclin@uol.com.br
Conflict of interest: none Financial source: none

Received: January 10, 2006

Review: February 18, 2006

Accepted: March 21, 2006

How to cite this article:

Monteiro RLR, Andreollo NA, Rodrigues MAM, Araujo MR. Gastric proliferative lesions induced by duodenogastric reflux in rats. Acta Cir Bras. [serial on the Internet] 2006 July-Aug;21(4). Available from URL: http://www.scielo.br/acb 